\title{
Lessons from the Alternative Dispute Resolution Movement
}

\author{
Jethro K. Lieberman $\dagger \&$ James F. Henry $\dagger \dagger$
}

In less than a decade, alternative dispute resolution-ADR - has grown from a bravely-voiced hope to a congeries of practices animated by the desire to resolve legal battles outside the courtroom. ${ }^{1}$ ADR offers a way-station, or a series of them, between the probity of the adversary system and the flexibility of private negotiations. ${ }^{2}$ Though not without an ideology, ADR has never had a unified theory to explain what it accomplishes and how it works. But enough experience has accumulated by now to permit a search for a more analytical understanding of ADR and the lessons it might teach.

\section{WHAT IS ADR?}

The ADR roster includes such well-known processes as arbitration, mediation, conciliation, and, perhaps, negotiation. These processes can be used to settle existing disputes or to prevent disputes from developing. ${ }^{3}$ There are also new hybrid devices that borrow from courtroom procedure-including, most prominently, the mini-trial. ${ }^{4}$ The roster may also be expanded to include the

†Visiting Associate Professor, New York Law School.

††President, Center for Public Resources, New York.

1 Groups advocating ADR include the Legal Program of the Center for Public Resources (including its Judicial Panel), the American Arbitration Association, the Special Committee on Dispute Resolution of the American Bar Association, the Alternative Dispute Resolution Section of the Association of American Law Schools, the Society of Professionals In Dispute Resolution (known as SPIDR), and certain for-profit companies, for example, EnDispute, Inc.

${ }^{2}$ Cf. Fuller, The Forms and Limits of Adjudication, 92 HARv. L. REv. 353, 363-64 (1978) (discussing contract and adjudication as forms of social ordering involving different modes of participation by affected parties); $i d$. at 406-07 (discussing "mixed" forms).

3 See The Role of Courts in American Society 94-97 (J. Lieberman ed. 1984) [hereinafter cited as THE ROLE OP CouRTs].

4 See, e.g., Erika S. Fine, The CPR Legal Program Mini-Trial Workbook (1985); J. Hengy \& J. Lieberman, The Manager's Guide to Resolving Legal Disputes chs. 3-6 (1985); Green, Growth of the Mini-Trial, Litigation, Fall 1982, at 12; Parker \& Radoff, The Mini-Hearing: An Alternative to Protracted Litigation of Factually Complex Disputes, 38 Bus. LAw. 35 (1982). 
roles played by certain officials and quasi-officials ${ }^{5}$ (such as courtappointed masters, special masters, ${ }^{6}$ and neutral experts), by private persons retained as neutrals, ${ }^{7}$ by ombudsmen, ${ }^{8}$ and by private judges. ${ }^{9}$ Changes in procedural rules to provide incentives to the parties to settle (for example, further penalizing parties who turn down reasonable settlement offers ${ }^{10}$ ) and the greater use of partial summary judgment ${ }^{11}$ might also be viewed as ADR techniques.

It is easier to point to discrete practices than to discern the entire direction of the new movement. ADR has no generally accepted abstract or theoretical definition. But it does have a fundamental premise: it is worthwhile both to reduce the costs of resolving disputes, however this can be accomplished, and to improve the quality of the final outcome. We offer a working definition of $\mathrm{ADR}^{12}$ as a starting point for analysis: $\mathrm{ADR}$ is a set of practices

S See, e.g., Green, Getting Out of Court-Private Dispute Resolution, Boston B.J., May/June 1984, at 18; Alabama Inaugurates Court Expert Plan, Alternatives to The High Cost of Litigation, Aug. 1982, at 5.

- See, e.g., W. Brazil, G. Hazard \& P. Rice, Managing Complex litigation: A PractiCAl Guide to the Use of Spgcial Masters (1983); Brazil, Referring Discovery Tasks to Special Masters: Is Rule 53 a Source of Authority and Restrictions?, 1983 AM. B. Found. RESEARCH J. 143.

7 See, e.g., W. Warren Knight, Justice Outside the System 6, 9, 35 (Premier Publishing Co. 1984); Feinberg Mediates Private Antitrust Suit, AltzRnatrves to THE High Cost of Litigation, July 1985, at 1; Morris, The Mini-Trial from the Perspective of a Neutral Aduisor, CPR Legal. Program Proceedings, June 1983, at 21.

- See, e.g., Walter Grelhorn, WhEn Americans Complain 39-56 (1966); Robbins \& Deane, A Non-Adversary Solution for Employee Conflicts, ALternatives to the High Cost of Litigation, Aug. 1985, at 6; Rowe, The Non-Union Complaint System at M.I.T.: An Upward-Feedback, Mediation Model, Alternatives to the High Cost of Litigation, April 1984, at 10; Rowe, The Non-Union Complaint system at MIT, in Proceedings of the First National Conference on Resolving EEO Disputes without Litigation, Washington, D.C., Jan. 1984, at 24, 38; American Optical Co., Ombudsman Program, in id. at 76 (on file with The University of Chicago Law Review).

- See, e.g., Green, Avoiding the Legal Logjam: Private Justice, California Style, in Centrer for Public Resources, Corporate Dispute Managrment 1982, at 65-89; Green, Private Judging: A New Variation of Alternative Dispute Resolution, Trial, Oct. 1985, at 36.

so See Note, Rule 68: An Offer You Can't Afford to Refuse, 37 Rutgers L. Rev. 373 (1985) (suggesting alteration of rule 68 to allow either party to invoke the rule, to limit judicial discretion in determining the reasonableness of an offer, and to allow adequate discovery before offers); Note, Rule 68: A "New" Tool for Litigation, 1978 DukE L.J. 889 (suggesting increased judicial discretion in the rule 68 cost-shifting provision).

"For an analysis and critique of current summary judgment practice in the federal courts, see Schwarzer, Summary Judgment Under the Federal Rules: Defining Genuine Issues of Material Fact, 99 F.R.D. 465 (1984).

12 This definition is distinctly different from that implied by one of the leading critics of ADR, Professor Owen M. Fiss-namely, that ADR is the creation of incentives or pressures that force litigants to settle. See Fiss, Out of Eden, 94 YALE L.J. 1669, 1670 (1985). For a response to Fiss's critique of ADR, see infra text accompanying notes 39-47. 
and techniques that aim (1) to permit legal disputes to be resolved outside the courts for the benefit of all disputants; (2) to reduce the cost of conventional litigation and the delays to which it is ordinarily subject; ${ }^{13}$ or (3) to prevent legal disputes that would otherwise likely be brought to the courts. ${ }^{14}$

This paper focuses on the first part of the definition-private resolution of existing legal disputes outside the courts. ${ }^{15}$ The "disputes" with which ADR is centrally concerned should be distinguished from "problems," "grievances," or "claims."16 Problems are the troubles that affect the human lot, such as damage from storms or sudden illness. Grievances are those problems that affect a particular person, but which may or may not have a particular person or group as the cause of the distress. When the sufferer asks the person thought to be causing the grievance to forbear, the grievance has become a claim or complaint. But a dispute arises only when the one against whom the complaint is lodged fails to respond satisfactorily to the aggrieved party. And a "legal" dispute arises only when the claim is grounded in a legal entitlement. ADR, then, should be viewed as a set of practices that are truly alternatives to the courts for the resolution of disputes that could legitimately be disposed of by judicial decree.

Finally, ADR can be "alternative" in one of two senses: because the parties privately choose to avoid litigation (or to terminate it short of judgment), or because legal rules require or permit the courts to send the dispute elsewhere (as in court-annexed arbitration). The analysis that follows largely takes the perspective of parties who have privately and voluntarily chosen to resolve their

1s Speed should not be seen as the sine qua non of a non-adjudicative process. Some ADR processes take longer than traditional adjudication-for example, the joint review process. See Conference Proceedings, Rocky Mountain Mineral Law Foundation, Denver, Colorado, March 22-23, 1984.

14 This third part of the definition is responsive to public debate over the nature and growth of litigiousness in the United States. See JeTHRo LIEBERMan, The Litigious SocIETY (1981); Galanter, Reading the Landscape of Disputes: What We Know and Don't Know (and Think We Know) About Our Allegedly Contentious and Litigious Society, 31 UCLA L. REv. 4 (1983).

1s Nevertheless, it is well to remember that if the aim is to reduce the incidence of litigation in the United States and its attendant costs, it is highly relevant to find ways to prevent disputes from arising and to minimize the cost of litigating those disputes that must go to court.

16 This distinction is developed in Felstiner, Abel \& Sarat, The Emergence and Transformation of Disputes: Naming, Blaming, Claiming . . . , 15 LAw. \& Soc'y REv. 631 (1981); see also The Role of Courts, supra note 3, at 86-87; Miller \& Sarat, Grievances, Claims, and Disputes: Assessing the Adversary Culture, 15 LAw \& Soc'y Rev. 525 (1981). 
disputes outside the formal procedures of adjudication. ${ }^{17}$

\section{The Theory Behind ADR}

\section{A. Opening the Lines of Communication}

What often prevents disputes from being resolved is a failure to communicate stemming from a lack of trust between the parties. ADR is premised on the hypothesis that if the parties could overcome this distrust, they could voluntarily reach a settlement as just as the result a court would impose.

The adversary process-the engine of the adjudicatory system-operates on a theory of fundamental distrust: Never put faith in the adversary. Litigation thus becomes formal, tricky, divisive, time-consuming, and distorting. These characteristics are reflected in the common image of discovery in large-scale commercial cases that takes years to conduct, in the careful coaching and preparation of witnesses, and in the skillful impeachment of sound witnesses during cross-examination. ${ }^{18}$ In contrast, the creation of trust is central to the design of many ADR processes.

Consider the example of the mini-trial. The mini-trial is not in fact a trial at all, but a highly-structured settlement process. Because it is a flexible device that can be tailored to the precise needs of the parties, no single procedural model of the mini-trial has yet prevailed. But in general, the known mini-trials share many of the following characteristics: ${ }^{19}$

1. The parties negotiate a set of procedural ground rules (a protocol) that will govern the nonbinding mini-trial.

2. The time for preparation is relatively short-between six weeks and three months-and the amount of discovery is relatively limited.

3. The hearing itself is sharply abbreviated-usually no more

17 The narrow focus of this paper should not be taken to mean that the movement among judges to explore alternatives to traditional procedures is not central to ADR. In fact, the ADR movement perhaps had its modern beginnings at the Pound Conference, at which Professor Frank E.A. Sander introduced the concept of the "multi-door courthouse"-that courts could use different processes to resolve disputes in different "rooms." Sander, Varieties of Dispute Processing, 70 F.R.D. 111, 126-34 (1976). This paper suggests, however, that the perspective of private parties voluntarily choosing among available procedures should form the baseline of any evaluation of the judicial adaptation of ADR techniques.

16 For critiques of the adversarial system, see Marvin Frankgi, Partisan Justice 3-69 (1981), and ANNe STRICK, INJUSTICE FOR Ale 37-57 (1977).

19 These characteristics are discussed in some detail in J. HENRY \& J. LIEBERMAN, supra note 4 , at $26-35$. 
than two days.

4. The hearing is often conducted by a third-party neutral, typically called the "neutral advisor."

5. The case is presented to representatives of the parties with authority to settle; there is no judge or jury.

6. The lawyers present their "best" case; they do not have time to delve into side issues.

7. Immediately after the hearing, the party representatives meet privately to negotiate a settlement.

8. If they cannot reach a settlement, the neutral advisor may render an advisory opinion on how he thinks a judge would rule if the case were to go to court.

9. The proceedings are confidential: the parties generally commit themselves to refrain from disclosing details of the proceedings to any outsider.

Several observations are in order about the trust-building capacity of the mini-trial. First, the very process of negotiating the protocol tends to foster trust. ${ }^{20}$ Second, by concentrating on their best possible case, the lawyers usually feel constrained to discuss the central issues. Third, the kind of lawyerly hairsplitting, namecalling, and pettifogging that might delight courtroom regulars would leave the business executives to whom mini-trials are presented singularly unamused. Finally, the presence at the hearing of a neutral advisor, to whom both parties have consented, enhances the prospect that they will credit any advisory opinion that he renders.

Mediation leads to the building of trust in a somewhat different way. Mediation permits a neutral to learn intimate facts from both sides that they would never have shared with each other in the course of trial preparation. By building on the parties' trust in the mediator, the process thus allows the parties to explore workable options. With the knowledge that he gains, the mediator can learn how far apart the parties are and devise ways of bridging the gap.

One lesson that ADR teaches, then, is that processes designed to restore and build trust can overcome the suspicion and mutual hostility fostered by the adversary system and can lead the parties

${ }^{20}$ It might be objected that this prospect is circular: only if the parties trust each other at least to a limited extent will they agree to conduct a mini-trial at all. But experience suggests that they need not trust each other very much at the outset. Their need to negotiate in order to gain access to the forum tends to foster trust, and their desire to save further litigation costs might simply overwhelm the distrust. 
to settle their differences. When the substantive outcome is compared to the likely result in court-and the costs of continued litigation are weighed in the balance-both parties generally benefit from ADR.

\section{B. The Superiority of Results}

A working hypothesis of $\mathrm{ADR}$ is that the results of $\mathrm{ADR}$ are often superior to court judgments-and even more clearly superior to conventional settlements. Although the hypothesis is difficult to test, it is supported by several considerations.

First, adjudication is characterized by a "winner-take-all" outcome. ${ }^{21}$ This cannot be wholly true, for jury damage awards can work compromises, and the parties can shape consent decrees through bargaining. Nevertheless, in many cases, the fundamental issue of liability can be resolved only by holding for the plaintiff or the defendant. ADR, by contrast, is not bound by the zero-sum game of adjudication. While we have defined ADR as concerned with "legal disputes," participants in ADR are free to go beyond the legal definition of the scope of their dispute. They can search for creative solutions to the problem that gave rise to the dispute, and those solutions may be far more novel than any remedy a court has the power to provide. In a mini-trial held by Texaco and Borden, for example, the parties resolved a breach-of-contract claim and antitrust counterclaim totaling in the hundreds of millions of dollars by renegotiating the entire contract for the supply of natural gas. Both parties claimed a net gain. ${ }^{22}$ No court could have ordered the parties to renegotiate; at best a judge or jury could only have compromised on the amount of damages it awarded the "winner."

Second, in classes of cases involving complex institutions, negotiations conducted by executives are likely to yield results superior to those conducted by the lawyers. ${ }^{23}$ The executives are far

21 See Howard Raiffa, The Art and Science of Negotiation 33-35 (1982); MenkelMeadow, Toward Another View of Legal Negotiation: The Structure of Problem Solving, 31 UCLA L. REv. 754, 783-89 (1984).

22 See Texaco-Borden Antitrust Mini-Trial Sets Record, Alternatives to the High Cost of Litigation, March 1983, at 1, 3.

23 Such is the common claim in gatherings of ADR proponents, although it is difficult to document. In remarks at the midyear meeting of the CPR Legal Program, Professor James Sebenius of the Kennedy School of Government suggested that managers negotiate better than lawyers because they can invent options that go beyond the narrow focus of the issues in dispute. The best negotiation, he suggested, occurs when managers are teamed with lawyers. Management Roundtable: Roles of Senior Executives in Preventing, Managing, 
more familiar than their lawyers with the nuances of their business and can respond more quickly and creatively to proposals raised by their counterparts. We do not mean to diminish the role or responsibilities of lawyers in the negotiations; their legal knowledge will often be crucial to successful settlements and good lawyer-negotiators may be more skillful than poorly trained executive-negotiators. Nevertheless, the business executive may be presumed to be less distracted by the shadow the law casts over the dispute; ${ }^{24}$ the executive will look at the complete business picture, unconstrained by the narrow parameters imposed by legal doctrine. ${ }^{25}$

Third, direct involvement by the client can obviate or minimize difficulties arising from the self-interest of lawyers. This point may be particularly instructive for judges. By requiring clients to attend pretrial conferences, judges can be sure that the clients know and approve of the propositions their lawyers will assert in court on their behalf. ${ }^{28}$

Fourth, ADR techniques and processes can be far more systematic than the horsetrading of conventional settlement negotiations. Settlement negotiations are often perceived as consisting of sharp tactics and bluff. ${ }^{27}$ "Unprincipled" negotiations occur in large part because the parties lack a means of communicating with each other. ADR processes permit realistic assessments of whether offers and counteroffers are in good faith.

Fifth, properly designed ADR processes make it more likely that settlement decisions will be based on the merits of disputes. As Richard A. Posner has suggested, various factors may contribute to more or less settlement. ${ }^{28}$ Delay in the judicial system tends to "increase[] the likelihood of settlement by reducing the stakes in the case," in part because delay diminishes the present value of the ultimate award. ${ }^{29}$ Other factors include rules governing prejudgment interest and the availability of pretrial discovery. ${ }^{30}$ This

and Resolving Disputes, CPR Legal Program Proceedings, Feb. 1985, at 28.

${ }^{24}$ Cooter, Marks \& Mnookin, Bargaining in the Shadow of the Law: A Testable Model of Strategic Behavior, 11 J. Legal STud. 225 (1982).

${ }^{25}$ See generally Menkel-Meadow, supra note 21 (contrasting adversarial and problemsolving modes of negotiation).

${ }^{28}$ See Federal Judges Urge CEOs to Come to Chambers Early, Auternatives to the High Cost of Litigation, Jan. 1983, at 5 [hereinafter cited as CEOs].

${ }^{27}$ For a contrary view, see R. Fisher \& W. URY, GetTing to Yes (1981).

${ }^{28}$ See Posner, An Economic Approach to Legal Procedure and Judicial Administration, 2 J. Legat STUd. 399, 417-29 (1973).

${ }^{29} \mathrm{Id}$. at 420 (under certain assumptions).

so Id. at 421-27. Not all discovery provisions facilitate settlement according to this model. See id. at 426-27 (discussing insurance-coverage and medical-examination rules). 
analysis could lead the courts to advocate policies that would increase delay (or other costs of litigation) in order to prompt settlement. The resulting settlements would not necessarily be just, however, because they would not have taken account of power disparities. The party with the more meritorious claim might not prevail because he is too poor to amass the requisite evidence through the discovery process. Society may have the power to foster higher settlement rates by manipulating the factors that induce people to stay out of court, but many proponents of ADR would not view such policies as consonant with the ADR philosophy. A dispute should not merely be settled; it should be settled justly.

As a simple example of this difficulty, the divorce mediation model has lately come under attack from feminists and others precisely because in that model-where husband and wife are in a room with a mediator attempting to resolve their financial affairs and custody arrangements-neither participant has an attorney, and the spouse with superior knowledge and staying power will be able to force a better and possibly unjust settlement. ${ }^{31}$ Responsible proponents of ADR do not advocate settlement at any cost. The ADR processes now being implemented are designed to reflect the dual notion that settlements should be both just and efficient.

Finally, a sixth reason to think that ADR leads to "better" outcomes is that the use of private neutrals permits the parties to submit their dispute to one with greater expertise in their particular subject than does the luck of the draw in the courtroom. Many complex disputes involve data and concepts that lie beyond the knowledge of generalist judges (and of all juries). The ADR neutral can be selected for a particular expertise, thus saving the parties the cost of educating the fact-finder (and the risk of failing to do so). Moreover, if the parties have personally participated in selecting the neutral, they may be psychologically disposed to accept his statement of the case, whether it is a binding decision (as in arbitration) or an advisory opinion (as in a mini-trial).

31 Compare Herman, McKenry \& Weber, Mediation and Arbitration Applied to Family Conflict Resolution, 34 ARB. J. 17, 19 (1979) ("successful negotiation of the settlement agreement includes equalization of power"), with Kressel, Deutsch, Joffe, Tuchman \& Watson, Mediated Negotiations in Divorce and Labor Disputes: A Comparison, 15 ConcilinTION CourTs Rev. 9, 11-12 (1977) (since power disparities create "strong pressures on the mediator" to side with the wife and threaten the mediator's impartiality, each side should be provided with an advocate). 


\section{Is ADR Socially Valuable? A Response to the Critics}

Proponents of ADR suggest that its value lies in reducing the burden on courts and disputants. Alarmed at the ever-increasing numbers of cases filed, ${ }^{32}$ the Chief Justice ${ }^{33}$ and others ${ }^{34}$ see arbitration and other practices as ways of removing large individual cases and even large classes of cases from the courts, thus removing a burden from the shoulders of judges (while shifting it to someone else). To the delight of their critics, they have occasionally forgotten that whether this change is beneficial depends on the relative justice and expense of dispositions through formal in-court adjudication and through less formal out-of-court methods of dispute resolution.

Critics of ADR, like Owen Fiss, ${ }^{35}$ suggest that ADR proponents mistake the function of courts as "mere" dispute resolvers. By diverting cases from courts, society loses the benefit of courtsanctioned judgments:

The advocates of ADR are led . . . to exalt the idea of settlement more generally because they view adjudication as a process to resolve disputes. They act as though courts arose to resolve quarrels between neighbors who had reached an impasse and turned to a stranger for help. Courts are seen as an institutionalization of the stranger and adjudication is viewed as the process by which the stranger exercises power . . . . The dispute-resolution story makes settlement appear as a perfect substitute for judgment . . . by trivializing the remedial dimensions of a lawsuit, and also by reducing the social

s2 Case filings, the common measure of litigation rates, are misleading because so many filed cases are neither heard nor adjudicated in court. See The Role of CourTs, supra note 3 , at 29 .

ss See, e.g., Burger, Isn't There a Better Way?, 68 A.B.A. J. 274, 276-77 (1982) (advocating private binding arbitration as "'a better way to do it" ").

s4 See, e.g., Derek Bok, The President's Report to the Board of Overseers of Harvard College, 1981-1982, reprinted in N.Y. ST. B.J., Oct. 1983, at 8, and N.Y. ST. B.J., Nov. 1983, at 31; Cannon, Contentious and Burdensome Litigation: A Need for Alternatives, 63 NaT't Forum, Fall 1983, at 10; Ehrlich, Legal Pollution, N.Y. Times Mag., Feb. 8, 1976, at 17, 21; Footlick, Too Much Law?, NewsweEk, Jan. 10, 1977, at 42, 47; Manning, Hyperlexis: Our National Disease, 71 Nw. U.L. REv. 767, 780 (1977); Rosenberg, Let's Everybody Litigate?, 50 TEx. L. Rev. 1349, 1360-63 (1972); Tribe, Too Much Law, Too Little Justice, Atrantic MONTHLY, July 1979 , at 25.

ss We cite Fiss repeatedly here because he is the most articulate opponent of an ADR perspective; hence it is useful to test the propositions of ADR against his critique. We say "a" perspective because, as suggested in the text, Fiss tends to emphasize the perspective of the judge imposing an "alternative" procedure on unwilling litigants, rather than that of the consumer of legal services making a rational choice among available options. 
function of the lawsuit to one of resolving private disputes: In that story, settlement appears to achieve exactly the same purpose as judgment-peace between the parties-but at considerably less expense to society. ${ }^{36}$

Fiss also argues that advocates of ADR have an unstated political agenda: to keep the activist state from meddling with powerful private economic interests. ${ }^{37}$ Finally, Fiss suggests that settlements lack the legitimacy of cases fully adjudicated to judgment. ${ }^{38}$

Four responses to this critique are in order. One short answer to Fiss is that most ADR proponents make no claim for shunting all, or even most, litigation into alternative forums. The ADR movement of the 1980s does not suppose that every legal dispute has a non-judicial solution. Indeed, the ADR literature recognizes that some types of cases are not suited to resolution outside the courtroom, including particularly cases in which the plaintiff seeks a declaration of law by the court. ${ }^{39}$ Fiss overlooks this accepted limitation of ADR because he assumes, at least implicitly, that all cases resemble Brown v. Board of Education. ${ }^{40}$ But, of course, they do not. It seems obvious that large classes of cases are not so consequential, and do not call for the definitive ruling of a judge or the imprimatur of an official organ of the state. Automobile accidents, uncontested divorces, breaches of contract, and other common types of suits do not cry out to be memorialized in the official reports, and, in any event, most are settled far short of trial.

36 Fiss, Against Settlement, 93 YALE L.J. 1073, 1075, 1085 (1984).

37 "Chief Justice Burger is not moved by love, or by a desire to find new ways to restore or preserve loving relationships, but rather by concerns of efficiency and politics. He seeks alternatives to litigation in order to reduce the caseload of the judiciary or, even more plausibly, to insulate the status quo from reform by the judiciary." Fiss, supra note 12, at 1670.

ss Fiss, supra note 36 , at 1082 (rejecting the notion that settlement is legitimate because it is consent-based; instead, settlements are approved based on an imagined result at trial, without the benefit of adversary presentation).

30 In this sense, the current ADR movement has a different outlook from its precursors. Much of the energy of early reform movements was devoted to a search for a comprehensive elimination of formal adjudication. See generally Jerold AugraAch, Justice WrTHOut Law? (1983) (contrasting early community-based modes of dispute settlement with the post-1960s "legalization" of these alternative modes). That is not the core of the modern argument. See, e.g., Civil Case Backlogs in Federal District Courts: Hearings Before the Subcomm. on Courts of the Senate Comm. on the Judiciary, 98th Cong., 1st \& 2d Sess. 197 (1984) (statement of James F. Davis) ("If there are overriding legal principles in a dispute, constitutional matters, statutory construction matters, grudge cases, and the like, a minitrial probably is not going to succeed.").

to 347 U.S. 483 (1954); see Fiss, supra note 12, at 1670 ("It would be nice if the blacks in Chicago ... did not have to go to court in order to obtain all the Constitution promises, and instead were able to work things out with the school board."). 
A second response to Fiss's critique is that his "conspiracy theory" of ADR is dubious. Many people who seek to use ADR are scarcely "powerful" economic interests-ADR is not limited to adoption by Fortune 500 companies. Moreover, ADR does not dispense with community norms. All dispute resolution takes place with an eye toward existing alternatives-including litigation. ${ }^{41} \mathrm{Fi}$ nally, the choice to employ ADR is made by parties who have determined that the injustice resulting from delay and the prohibitive costs of pursuing a case through the courts (direct expenditures for lawyers and expenses, as well as significant indirect expenditures, like lost opportunity costs) far outweigh any putative injustice stemming from the decision to forgo judgment by the court.

A third response to Fiss is that not all questions need to be answered. An open society needs the tension of open questions; parties who settle do not thereby foreclose answers at some later time when matters of principle are truly at stake and the issues cannot be compromised. Fiss agrees that avoidance has a value to society, "which sometimes thrives by masking its basic contradictions." ${ }^{42} \mathrm{He}$ questions, however, whether settlement will result in too much avoidance. ${ }^{43}$ But we know of no way to measure the appropriateness of avoidance. Furthermore, Fiss's concern is onesided. We should be equally concerned to prevent courts from rendering judgment when settlement is more appropriate.

Finally, Fiss's position is seriously weakened by his failure to offer proof that court judgments are more just. He says, for example, that "[a]djudication is more likely to do justice than conversation, mediation, arbitration, settlement, rent-a-judge, mini-trials, community moots or any other contrivance of ADR, precisely because it vests the power of the state in officials who act as trustees for the public, who are highly visible, and who are committed to reason."44

Does ADR reach a just result or merely an expedient one? How can one measure the justice of a private settlement? The question is important, but it has not been well discussed in the ADR literature-no doubt because it is so difficult a proposition to test. Whatever the answer, it seems fair to ask the same questions

41 See supra note 23 and accompanying text; Mnookin \& Kornhauser, Bargaining in the Shadow of the Law: The Case of Divorce, 88 YaLE L.J. 950 (1979).

12 Fiss, supra note 36 , at 1086.

is Id.

44 Fiss, supra note 12, at 1673. 
of courts. In theory, courts are committed to reason, but in practice much stands in their way. Some judges are dispassionate and disinterested seekers after justice, but not all are. And all judges are busy; it is a fair assumption that they do not have sufficient time to devote to any single case. ${ }^{45}$ Moreover, the maneuvering of partisan lawyers alone is often enough to ensure that justice will not be done. ${ }^{18}$

A perhaps more controversial response to Fiss's argument about the quality of outcomes is that in certain important classes of cases-cases involving public institutions like schools, hospitals, and prisons (the very cases that particularly interest Fiss)-courts themselves invoke processes that are firmly lodged in the ADR arsenal. Stories that describe litigation over unconstitutional prison conditions, inhumane mental hospital conditions, and segregated schools frequently depict the judge acting as mediator, helping the parties to negotiate the remedy the court will impose by consent decree. ${ }^{47}$ If the courts themselves find these processes useful or even necessary, chances are good that the same processes can be as beneficial when invoked outside the courts.

\section{ApPlications for JUDGes}

It is in an important sense anomalous to suppose that judges can discern in the private ADR movement any practical applications for use within the courts, since the very premise of ADR is that it is a consensual process designed to circumvent judicial process. If the parties are before the court, they are presumably there because they seek adjudicatory procedures to resolve their dispute or because they could not agree on private procedures to do so. In either event, judges may not impose procedures outside the scope of the rules. Nevertheless, the modest success of ADR so far suggests two possibilities, one more difficult than the other.

One possibility lies in changing the rules themselves. Proce-

48 For a general discussion of the problem of delay, see The Courts, the Public, AND THE LAW ExpLosion 31 (H. Jones ed. 1964) ("[A] lot more is said about court delay than is known about it. But how thick a supporting dossier need one collect to take a stand against sin? And that is what, by common repute, delay is-an unmitigated evil.").

16 See M. Frankrl, supra note 18, at 21-38.

17 See, e.g., Chayes, The Ordinary and the Extraordinary in Institutional Litigation, 93 HARv. L. REv. 465, 481-86 (1980) (increase in judicial participation as litigation complexities increase); Eisenberg \& Yeazell, The Role of the Judge in Public Law Litigation, 89 Harv. L. Rev. 1281, 1296-1302 (1976) (same); see also Martin Shapiro, Courts 8-9 (1981) ("Mediating is not to be seen as an antithesis to judging, but rather as a component in judging."). 
dures too cumbersome could be made more flexible; procedures too unlikely to be invoked could be made more accessible. The object here is not to design procedures that will keep cases from coming to court, not to aid judges with overfull calendars. Rather, the courts could, by local rule or legislative action when necessary, streamline processes that are underused.

Thus two ADR advocates have recently proposed streamlining the Federal Rules of Civil Procedure to permit cases to go forward along a "fast track." 48 They propose that the parties be permitted to elect an expedited schedule of discovery that would guarantee a trial date within 12 months.

Another type of ADR within the courts is the summary jury trial. The brainchild of U.S. District Judge Thomas D. Lambros (N.D. Ohio), the summary jury trial is the courtroom equivalent of the mini-trial. A case is presented during the course of a single day to a mock jury consisting of jurors drawn from the real jury pool; the jurors do not know until after they have rendered their verdict that it is not binding. In thus giving the parties a "real" verdict, the procedure creates an incentive for them to settle their case privately. The record to date suggests a high settlement rate (more than ninety percent in Judge Lambros's courtroom)..$^{49}$ The summary jury trial has been adopted in a number of federal courts, either by local rule ${ }^{50}$ or by individual judges, ${ }^{51}$ and has been formally endorsed by the Judicial Conference of the United States. ${ }^{52}$

Even with rules changes, these devices require the consent of the parties, and so in that sense can be considered ADR mechanisms. ${ }^{53}$ Consent is central to the other possible approach to using

18 See McMillan \& Siegel, Creating a Fast-Track Alternative Under the Federal Rules of Civil Procedure, 60 Notre Dame L. Rev. 431 (1985).

49 See M.D. Jacoubovitch \& C. Moore, Summary Jury Trials in the Northern DisTRICT OF OHIo (Federal Judicial Center 1982); A Compendium of Judicial ADR, ALTERNAtives to the High Cost of Litigation, Special Issue 1985, at 6 [hereinafter cited as Compendium].

${ }^{\text {so }}$ E.g., W.D. Mich. Crv. R. 44.

s1 The districts in which judges have used the summary jury trials include Colorado, Connecticut, Florida (S.D.), Illinois (N.D.), Massachusetts, Michigan (E.D), Montana, Ohio (S.D.), Oklahoma (W.D.), and Pennsylvania (M.D. and E.D.). Compendium, supra note 49, at 7; Ranii, Summary Jury Trials Gain Favor, Nat'l L.J., June 10, 1985, at 1, 30.

32 "Resolved, that the Judicial Conference endorses the experimental use of summary jury trials as a potentially effective means of promoting the fair and equitable settlement of potentially lengthy civil jury cases." Report of the Proceedings of the Judicial Conference of the United States, Washington, D.C., Sept. 19-20, 1984, at 88; see also Compendium, supra note 49 , at 4 , col. 3 .

ss Even where participation in the summary jury trial process is mandatory when the judge deems the process appropriate, as in the Northern District of Ohio, the process may 
ADR in court: developing procedures permitted under existing rules in order to incorporate the trust between the adversaries that is the central feature of all ADR devices. This approach, already used by judges in many contexts, calls essentially for involving the parties themselves in the litigation, not merely as witnesses but as active participants with the lawyers.

Thus, to take the simplest example, a judge could require executives of disputing corporations to appear in chambers with the lawyers at a pretrial conference under rule $16{ }^{54}$ As already noted, ${ }^{\mathrm{ss}}$ the judge at the pretrial conference can often expedite a case by insuring that the litigants themselves understand exactly what their lawyers are doing. ${ }^{56}$

\section{THE Future OF ADR}

The best use for ADR may be to resolve the types of cases that are extremely difficult or exceedingly costly to resolve in court. ADR is now being used to resolve multi-party cases. ${ }^{57}$ This range of actions is perhaps typified by the more than 30,000 asbestos-related personal injury cases flooding courtrooms across the country. ${ }^{58}$ But even ordinary commercial and antitrust cases in which many defendants are sued in the same action can be ren-

nonetheless be seen as consensual because the summary jury verdict is not binding.

54 And see especially, FED. R. Crv. P. 16(c)(7), permitting the parties to "consider and take action with respect to . . . the possiblity of settlement or the use of extrajudicial procedures to resolve the dispute."

ss See supra note 26 and accompanying text.

s8 "In one case, the parties were about to embark on a series of depositions to establish whether one of the companies was doing business in Illinois under the long-arm statute. There had been considerable wrangling by the attorneys before the conference, and they went at it heatedly in front of [U.S. District] Judge [John F.] Grady [N.D. Illinois]. As it happened, the judge had asked that the two chief executive officers be present; they listened to the debate more and more incredulously, until one finally blurted out: 'There isn't any question that we do business in Illinois.' Potential months of discovery was thus eliminated." See CEOs, supra note 26 at 5 .

87 It has become increasingly apparent that the conventional tools of litigation are inadequate to resolve these kinds of disputes. The most compelling illustration is the spectacle of an asbestos proceeding housed in a converted auditorium, in which the judge felt compelled to install traffic signals on his desk to indicate which of the more than 100 lawyers wished to object to the admission of evidence. Galante, Megatrials, Nat'l L.J., March 25,1985 , at 1,36 .

s Deborah Hensler, Asbestos in the Courts: The Challenge of Mass Toxic Torts 24 (1985). For other types of multi-party cases, see, for example, Morton MinTz, AT ANY Cost: Corporate Greed, Women, and the Dalkon Shizld 175-246 (1985); Levine, Gilding the Lilly, A DES Update, TriaL, Dec. 1984, at 18; A.H. Robins Files Chapter 11, Cites Dalkon Litigation, L.A. Daily L.J., Aug. 22, 1985, at 1. 
dered more manageable by the use of ADR techniques. ${ }^{.9}$

Attempting to fit a many-sided dispute into the two-sided contour of the adversary system can be worse than jamming the proverbial square peg into the round hole. More flexible processes are often necessary to bring matters to a successful and equitable resolution. In the asbestos litigation, mediation has tentatively proved itself by bringing together more than thirty producers and insurers in a pact, mediated by former Yale Law School Dean Harry $\mathrm{H}$. Wellington, to submit claims for rapid payout to the so-called Asbestos Claims Facility. Although the Facility will not automatically honor any claim presented, use of the Facility is expected to be faster than litigation, and should radically simplify the proof required of plaintiffs. The mediation took two years-far shorter than the time most asbestos cases have taken to get to trial..$^{60}$

In the end, however, we have only begun to identify the kinds of disputes likely to be amenable to the techniques of ADR. Disputes arise for various reasons-greed, envy, anger, revenge, principle-and can be settled (or not) for various reasons. Disputes can have very different legal characteristics. Likewise, the relationship between the parties varies from dispute to dispute: parties with a historic and continuing relationship will presumably have a different reaction to a dispute and its potential settlement than parties who have met on just this one occasion and will never meet again. How these axes of difference relate is an important and unresolved question.

We therefore need a typology of disputes to help determine which kinds of cases are amenable to ADR and which should be left to the traditional devices of adjudication. Among the relevant factors are: the number, nature, and relationships among the parties; the relief sought; the nature of the claim; the nature and standard of proof; the cost of formal adjudication (including potential delays); and the financial strength and risk aversion of the parties (including the degree of plaintiff's urgency for relief and the strength of defendant's desire to delay judgment). A matrix of these factors will no doubt be complex, and we must resist the

so See Alternative Dispute Resolution Techniques, 53 ANTrTrust L.J. 271 (1984); Warshauer, Litigation Management Techniques, Alternatives to the High Cost of LitigaTHON, Nov. 1984, at 7.

${ }^{80}$ There are no published statistics on how long asbestos cases take to get to trial. An educated guess by Professor Eric D. Green, a special master in the consolidated asbestos proceedings in the U.S. District Court for the Northern District of Ohio, is that they range from eighteen months to eleven years. Conversation with Eric Green, Center for Public Resources, March 1986. 
temptation to think that mathematical formulas will reveal with any precision which process is most appropriate for a particular kind of case. But without some deeper understanding of the crucial differences among types of disputes, we will never be able to weigh the competing claims of justice and efficiency, and to design the processes that will best serve both. 